\title{
Environmental monitoring of the effects of conventional and artisanal gold mining on water quality in Ngwabalozi river, southern Zimbabwe
}

\author{
Simbarashe Mudyazhezha*, Reginald Kanhukamwe \\ Department of Soil Science and Agricultural Engineering, University of Zimbabwe, Mt Pleasant, Harare, Zimbabwe \\ Email address: \\ simmudy@hotmail.com (S. Mudyazhezha)
}

\section{To cite this article:}

Simbarashe Mudyazhezha, Reginald Kanhukamwe. Environmental Monitoring of the Effects of Conventional and Artisanal Gold Mining on Water Quality in Ngwabalozi River, Southern Zimbabwe. International Journal of Environmental Monitoring and Analysis. Vol. 2, No. 2, 2014, pp. 123-127. doi: 10.11648/j.ijema.20140202.20

\begin{abstract}
Mineral extraction contributes positive to the socioeconomic fabric of many African countries but has also contributed to the deterioration of environmental quality. It has been branded the most destructive industry in the world. This study sought to assess the effects of conventional gold mining which use cyanide for gold extraction and artisanal gold mining which uses mercury amalgamation on water quality in Ngwabalozi River. Along the river, there are gold panning activities upstream and a conventional mine downstream. Water samples were collected at four sampling points: 1) upstream of the gold panning activities; 2) just downstream of gold panning area; 3) upstream of the conventional mine; 4) downstream of the conventional mine. Benthic macro-invertebrates were also collected at the name four points, identified to family level and counted. Water samples were analyzed for mercury, iron, arsenic, sulphates and turbidity. There were significant differences $(p=0.000)$ in the measurements of mercury, arsenic, sulphates, taxa richness, total count of individuals, Shannon-Weiner index, evenness index and average tolerance scores among the four sampling sites. Gold panning activities were found to pollute Ngwabalozi River with mercury while the conventional mine polluted the river with sulphates. Gold panning activities also feed a lot of sand into the river resulting in high turbidity. Gold mining reduced the taxa richness, total count of individual and the diversity of benthic macro-invertebrate community in the river. There was pollution induced succession in the river as pollution sensitive species were replaced by pollution tolerant ones.
\end{abstract}

Keywords: Gold Panning, Water Quality, Ngwabalozi River, Mercury, Biomonitoring, Sulphates

\section{Introduction}

Mining has long been an important economic activity in Africa (Hilson, 2002). In Southern Africa, mining generates about $60 \%$ of foreign exchange for the SADC region, makes up to $11 \%$ of region's gross domestic product GDP) and 5\% of total employment (SADC Mining Sector, 2000). Although mining contributes positively to the socioeconomic fabrics of many African countries, a wide range of environmental complications has accompanies these socioeconomic benefits (Hilson, 2002). According to Chenje (2000), mineral extraction is the most destructive industry in the world to the environment. Gold mining involves conventional mining and small scale mining (gold panning) (Baird, 1999). Conventional mining use cyanide to recover the gold from the ore. The reaction of gold and cyanide results in the release of other heavy metals from the gold ore. Ore and waste stockpiles established on surface commonly contain significant amounts of sulphides and, with the passage of time, heavy metals, sulphates and other pollutants are dissolved and leached out by precipitation into local streams and community water resources. The impact of mineral pollution on an ecosystem may be severe and may result in the total elimination of animal life from the receiving waters (Ravengai et al., 2005).

Small-scale gold mining, currently being practised by over 300,000 people in Zimbabwe (Maponga and Ngorima, 2003) with an annual gold production of up to 5 tonnes (Maponga, 1997) uses mercury for the recovery of gold from the ore in a process called amalgamation (Shoko and Love, 2005). While artisanal mining is believed to sustain the livelihood of at least two million people in Zimbabwe, directly and indirectly through ancillary services and 
secondary economic activities (Maponga and Ngorima, 2003), its environmental impacts are quite evident. The mining operations feature a number of rudimentary practices that pollute the air and contaminate resident water bodies and soils (Hilson and van der Vorst, 2002). Gold panning has absolute dependence on the use of large amounts of water hence mining operations are located as close to water sources as possible and in some cases at the water source. Thus the greatest impacts of gold panning are on water source. The mining activities, which involve digging river banks and river beds cause erosion with large amount of sediment feeding the river system (Mondlane and Shoko, 2002, Pereira, 2009).

Water sources are also under the threat of chemical pollution. Mercury contamination associated with small-scale gold mining and processing represents a major environmental and human health concern in Eastern and Southern Africa (van Straaten, 2000). Mercury use is popular in gold panning because of its ability to simplify the process of gold recovery, low investment and its high recovery rates. Gravimetric material flow analyses show that $70-80 \%$ of the $\mathrm{Hg}$ is lost to the atmosphere during processing, $20-30 \%$ are lost to tailings, soils, stream sediments and water. For every $1 \mathrm{~g}$ Au produced, 1.2-1.5 g $\mathrm{Hg}$ are lost to the environment (van Straaten, 2000). An estimated 6 tonnes of mercury is used annually by illegal panners in Zimbabwe. However, about $50 \%$ of the mercury (3 tonnes) is lost on amalgam plates, barrels, to the atmosphere, and during retorting, and is thus a direct threat to the environment (Maponga and Ngorima, 2003). In Ghana, between 4 and 5 tons of mercury are reportedly released into the environment each year as a result of small-scale gold mining (World Bank, 1995). Mercury is a potent neurological toxicant that interferes with brain functions and nervous system (Pereira, 2009).

While a lot of studies have been carried out both regionally and nationally on the effects of mining on water quality, the majority of these studies investigated water quality using physicochemical variable without use of bioindicators. This study seeks to investigate the effects of both conventional and small scale gold mining on the water quality of Ngwabalozi river using an integrated approach of measuring the physiochemical variables as well as the biological variables. Small scale miners, who do not have proper waste disposal facilities, are continuously discharging mercury into Ngwabalozi River. How Mine, a conventional mine downstream of the small scale miners is also discharging its waste into the Ngwabalozi River.

\section{Materials and Methods}

\subsection{Site Description}

Ngwabalozi River is 30 kilometers south of Bulawayo; it stretches from Mzinyathini to Mzingwane dam. Along Ngwabalozi River there are small scale miners and How Mine (conventional). Small scale miners are upstream of
How Mine. How Mine has five slime dams of which slime dam number 5 is currently active. The other four Slime dames are under rehabilitation (revegetation).

\subsection{Sampling}

Four points were marked along Ngwabalozi River. Point 1 being the control was 900 meters upstream of small scale miners, point 2 being the small scale mining, point 3 was 500 meters upstream of How mine, point 4 was 500 meters downstream of How mine. At each of these points water samples for physicochemical analysis and benthic macro invertebrates were collected using a kick net method. The benthic macro-invertebrates were identified, counted classified for pollution tolerance using the South African Scoring System (SASS4) (Chutter, 1994). At each point three replicates of the water samples were collected were collected. The water samples were analyzed for sulphates, mercury, iron, arsenic and turbidity.

\subsection{Sample Analysis}

Chemical analysis testing for the following heavy metals (Iron, mercury, arsenic) was done using atomic absorption spectrophotometer (AAS). Sulphate content was analyzed using the precipitation method. Turbidity was measured in Nephelometric Turbidity Units (NTU) using nephelometer which measures the intensity of light scattered at 90 degrees as a beam of light passes through a water sample.

\subsection{Data Analysis}

Abundance, taxa richness and Shannon Wiener diversity index, Shannon Evenness index were used to measure biodiversity. Total abundance was the number of individual benthic macroinvertebrates belonging to all families in a sample. Taxa richness was obtained by counting the number of families found in a sample. The Shannon-Wiener index $\left(\mathrm{H}^{\prime}\right)$ was calculated using the formula:

$$
\mathrm{H}^{\prime}=-\sum_{\mathrm{i}=1}^{\mathrm{s}} \mathrm{pi} \ln \mathrm{pi}
$$

s: number of families.

pi: proportion of individuals per family in the community made up of $\mathrm{s}$ families with known proportions $\mathrm{p} 1, \mathrm{p} 2$, $\mathrm{p} 3, \ldots, \mathrm{ps}$.

The South African scoring system version 5 was used to provide the tolerance scores for families of benthic macroinvertebrates. South African scoring system score were obtained by adding score of each taxon found at a site. Average score per taxon values were obtained by diving the SASS score for each sample by the number of taxa at that site. SASS scores and averages score per taxon were compared with standards in guidelines for interpreting water quality to determine water quality and the results were recorded in Appendix A2. Minitab 16 was used for the ANOVA to test for significant differences between means of taxa richness, tolerance scores per taxon, Shannon Wiener 
index of diversity, Shannon Evenness Index (E1), mean concentrations of chemical parameters and turbidity. Microsoft Excel was used for calculating average score per taxon, South African scoring system scores and Shannon Wiener diversity index.

\section{Results}

\subsection{Physicochemical Variables}

There were significant differences in turbidity among the four sampling sites $(p=0.000)$. Turbidity was lowest at site 1 (3.45 NTU) and highest at site 2, the gold panning site (201.11 NTU). From site 2, going down stream, turbidity sharply decreased at site $3(5.61)$ but increased at site 4 (27.17) (Table 4.1) Significant differences were found in mercury levels among the four sampling sites $(p=0.000)$. Mercury concentration was lowest at site 1 (the control point) and increased thirtyfold at site 2 . Moving downstream from site 2 , mercury concentration decreased by a factor of three at site 3 but decreased significantly at site 4 (Table 4.2). Iron concentrations did not vary significantly along the stream $(\mathrm{p}=0.863)$. Iron concentrations remained invariably constant throughout the stream, ranging from 0.1 to 0.11 $\mathrm{mg} / \mathrm{L}$. There were significant differences in arsenic concentrations among the four sampling points $(p=0.000)$. Site 1 was significantly different from the other three sites while site 2, 3, and 4 were not significantly different from each other. Arsenic concentrations were lowest at site 1 $(0.01 \mathrm{mg} / \mathrm{L})$ and increased tenfold at site 2 but remained constant thereafter (Table 4.2). Sulphate concentrations at the four sampling sites showed significant differences $(\mathrm{p}=$ 0.000). Sulphate concentrations increased marginally downstream from site 1 up to site 3 and then sharply (twenty-seven fold) at site 4 .

Table 1. The means and standard deviations of selected chemical parameters from the four sampling sites.

\begin{tabular}{ccccc}
\hline \multicolumn{5}{c}{ Sampling Site } \\
Parameter & Site 1 & Site 2 & Site 3 & Site 4 \\
\hline $\begin{array}{c}\text { Mercury } \\
(\mathrm{mg} / \mathrm{L})\end{array}$ & $0.01(0.001)$ & $0.31(0.020)$ & $0.11(0.015)$ & $0.10(0.020)$ \\
$\begin{array}{c}\text { Sulphates } \\
(\mathrm{mg} / \mathrm{L})\end{array}$ & $8.47(0.208)$ & $13.57(0.245)$ & $18.87(0.384)$ & $526.49(0.576)$ \\
$\begin{array}{c}\text { Arsenic } \\
\mathrm{mg} / \mathrm{L})\end{array}$ & $0.01(0.001)$ & $0.10(0.012)$ & $0.10(0.006)$ & $0.10(0.010)$ \\
$\begin{array}{c}\text { Iron } \\
(\mathrm{mg} / \mathrm{L})\end{array}$ & $0.10(0.012)$ & $0.11(0.010)$ & $0.11(0.006)$ & $0.10(0.015)$ \\
$\begin{array}{c}\text { Turbidity } \\
(\mathrm{mg} / \mathrm{L})\end{array}$ & $3.45(0.200)$ & $201.11(2.870)$ & $5.61(0.290)$ & $27.17(0.360)$ \\
\hline
\end{tabular}

\subsection{Biotic Indices of Diversity}

There were significant differences in taxa richness among the four sites $(\mathrm{p}=0.000)$. Site 1 , which was the control site, had the highest taxa richness, averaging 9.67 species, followed by site 3 , then site 4 and lastly site 2 . Site 2 and 4 were not significantly different from each other while site was significantly different from the other three sites. Site 1 was also significantly different from the three other sites. Total count of individuals at the four sampling points showed significant difference among the sites $(p=0.000)$. Site 2 and 4 were not significantly different from each other while site 1 and 3 showed significant difference with each other and with site 2 and 4 . Site 1 had the highest abundance of individuals followed by site 3 , then site 4 and lastly site 4 . Shannon Weiner index of diversity showed significant difference among the four sampling sites with all the four sites significantly different from each other $(p=0.000)$. Shannon's Evenness Index also showed significant differences among the four sites and all the four sites were significantly different from each other $(p=0.000)$. There were significant difference in average tolerance score per taxon (ATSPT) $(p=0.000)$. Site 2 had the highest tolerance score, followed by site 4 , site 3 and lastly site 1 .

Table 2. The means and standard deviations of biodiversity indices and average tolerance scores per taxon (ATSPT) form the four sampling sites.

\begin{tabular}{|c|c|c|c|c|}
\hline \multicolumn{5}{|c|}{ Sampling Site } \\
\hline Parameter & Site 1 & Site 2 & Site 3 & Site 4 \\
\hline $\begin{array}{c}\text { Taxa } \\
\text { Richness }\end{array}$ & $9.67(1.53)$ & $2.33(0.58)$ & $6.33(0.58)$ & $3.33(0.58)$ \\
\hline $\begin{array}{c}\text { Total } \\
\text { Abundance }\end{array}$ & $74.00(7.00)$ & $7.33(1.53)$ & $23.67(5.03)$ & $11.33(1.53)$ \\
\hline $\begin{array}{c}\text { Shannon } \\
\text { Weiner }\end{array}$ & $2.07(0.08)$ & $0.41(0.05)$ & $1.05(0.09)$ & $0.59(0.05)$ \\
\hline $\begin{array}{l}\text { Evenness } \\
\text { Index (E1) }\end{array}$ & $0.93(0.02)$ & $0.38(0.03)$ & $0.67(0.03)$ & $0.54(0.04)$ \\
\hline ATSPT & $2.90(0.36)$ & $31.45(1.28)$ & $4.43(0.46)$ & $7.38(0.86)$ \\
\hline
\end{tabular}

\section{Discussion}

\subsection{Chemical Variables}

Most mine operators have access to only intermediate technology, their operations are rudimentary in design, and for various reasons, they have few concerns for the environment. Furthermore, African mines operating on a small scale tend not to be as heavily regulated as large-scale properties; virtually all of the environmental regulations in place in African countries are still in an infancy stage, and of those pertinent to mineral activity, most apply to large-scale mines and fail to regulate smaller operations appropriately (Hilson, 2000). Consequently, a number of environmental problems such as soil degradation, chemical contamination, and air pollution now persist throughout the industry. With small-scale mining activities intensifying throughout the continent, it is highly likely that disturbances will worsen, making it all the more crucial that practical environmental strategies are devised and implemented (Hilson, 2002).

Pollution from mercury alongside land degradation is the most pressing environmental problems in African small-scale mining. Mercury, which is used for amalgamation in artisanal gold mining, the largest segment of the small-scale mining industry, is typically dispensed untreated into the atmosphere and waterways where it is then transformed by microbes into toxic methylmercury (MeHg) (Hilson, 2002). Maponga 
(1997) discovered that panners along the Mazowe use much more rudimentary methods of mercury amalgamation than formal miners and are largely responsible for elevated levels of mercury found in surrounding soils, rivers, and plants. In fact, a study by Shoko and others (1993) found that $64 \%$ of Zimbabwean gold mines exhibit "poor chemical management" and smaller mines, because of financial constraints, cannot optimize the use of expensive chemical cleansing agents. The gold mining activities are mainly poverty driven and the majority of the miners are rural people, lacking sufficient knowledge in mining techniques and safety measures (Pereira, 2009). Mercury concentrations were lowest at site one which was upstream of the gold panning activities. Site 2, which was just downstream of the gold panning activities, had the highest concentration of mercury. Mercury concentrations decreased three fold going downstream of site 2. Mercury is usually converted into methylmercury in the muddy sediments of rivers and lakes by anaerobic bacteria and microorganisms (Baird, 1999). This process of methylmercury formation could possibly result in low mercury concentration in the water column. Mercury is also highly volatile and could have evaporated from the water column resulting in low concentrations downstream of site 2 .

Heavy metals exist naturally in the soil of the basin and are thus transported to the river system through the gold mining (Pereira, 2009). Tailings are local 'hot spots' with high concentrations of $\mathrm{As}, \mathrm{Pb}, \mathrm{Cu}$ and $\mathrm{Hg}$ (van Straaten, 2000). The concentration $(\mathrm{mg} / \mathrm{l})$ of iron was increasing down Ngwabalozi River, it increased at site 2 since iron is liberated as the small scale miners recover their gold during the amalgamation process. At point 4 the concentration of iron was unexpectedly low about 20 metres before point 3 , Ngwabalozi river is infested with typha plant. According to Sasmaz and other (2008), typha plant is a heavy metal accumulator and this may explain decreased iron concentration at site 4 when it was expected to rise as a result of discharge from How Mine. It seems not to accumulate mercury as its concentration did not decrease from site three to site four. According to Chenje (2000), the gold ore in Zimbabwe contains high levels of arsenic. Arsenic was lowest at site 1, which was upstream of gold panning and conventional mining activities. The concentrations increased eleven fold at site 2 as a result of liberation from gold panning activities and remained constant downstream. The possible reason why arsenic concentrations stagnated downstream of site 2 could be as a result of the typha plant which existing downstream. While the conventional mine downstream of site 2 was expected to release additional arsenic, the additional could have been mopped up by the typha plant.

The majority of materials and metals extracted from the Earth by mining occur naturally as sulphide ores or are associated with sulphide minerals. Ore and waste stockpiles established on surface commonly contain significant amounts of sulphides and, with the passage of time, heavy metals, sulphates and other pollutants are dissolved and leached out by precipitation into local streams and community water sources (Ravengai et al., 2005). Sulphate concentrations increased downstream from site 1 by about $50 \%$ but increased sharply at site 4 by a factor of twenty-nine. The sulphates must have drained from the slime dams into the river giving the high the concentration.

\subsection{Turbidity}

Small-scale mining operations are always located close to, and are supported by water bodies (Pereira, 2009). For artisanal alluvial gold panning operations, this involves the digging up of river channels and banks, paleochannels and their floodplains as well as surface trenching, using picks and shovels. In some cases, the mining requires the stripping of overburden to expose the mineral bearing horizons. Thus, the most noticeable effect of these operations is the siltation of rivers and dams, deterioration of water quality (Shoko and Love, 2005). The digging up of river banks and floodplains in alluvial gold panning results in feeding enormous amounts of waste sand, gravel and rock dumps into the river system (Pereira, 2009). On average, panners move an estimated 8 million tonnes of material annually and in the process destroy significant portions of riverbanks on either side of rivers (Maponga and Ngorima, 2003). More than half the panners in the Zambezi Basin use the destructive horizontal tunnelling method of extracting gold, resulting in the collapse of banks and widespread erosion (Zwane et al., 2006). Turbidity was highest at site 2 which was just downstream of the gold panning activities as a result of the digging up of river beds and banks thus feeding a lot of soil into the river system, which caused high turbidity. Turbidity decreased at site 3 but increased at site 4. While conventional mining doesn't physically disturb the river bed and banks, the mine discharge contains a lot of dissolved and suspended material which give rise to turbidity.

\subsection{Benthic Macro Invertebrates}

Site 2 recorded the lowest taxa richness, total count of individuals, Shannon, Weiner index and evenness index. This could be as a result of mercury toxicity especially dimethylmercury which is found in sediments where benthic macro-invertebrates are found. The few species found at site are very tolerant species as evidenced by the high average tolerance scores at this site. Site 1 had the highest species richness and highest total count of individuals. The species at this site were pollution sensitive species since they recorded the lowest average tolerance scores. After site 2, species richness and total count of individuals increased at site 3 and then dropped at site 4 . Site four is just downstream of How Mine where seepage and spillage from slim dam released pollutants into the river. While other pollutants were not marginally different at site 4 compared to site 3 , sulphates increased exponentially at site 4 . Associated with ores containing sulphide is not just suphates but also acid mine drainage which results in the acidification of waters. Thus the water could have been acidic at site 4 meaning only acidophiles could exist. The average tolerance score was 
also high at this site meaning the site was more polluted compared to site 3 .

\section{Conclusion}

How Mine is polluting Ngwabalozi River with sulphates, mainly from its slime dams. Gold panners are contributing significantly to the built up of mercury concentration in the river. The digging up of river beds and banks by gold panners is feeding a lot of sand into the river system resulting in high turbidity. The pollution caused by mercury pollution and suphates caused a reduction in species richness and total count of individuals. The pollution by mercury and sulphates caused induced succession where the benthic macro-invertebrate community changed from very sensitive to very tolerant at the polluted site.

\section{References}

[1] Baird, C. 1999. Environmental Chemistry. $2^{\text {nd }}$ Ed. W.H. Freeman

[2] Chenje, M. (Ed.), 2000. State of the Environment Zambezi Basin 2000. SADC/IUCN/ZRA/SARDC, Maseru/Lusaka/Harare.

[3] Chutter, F.M. (1994), The rapid biological assessment of streams and rivers water quality by means of the macroinvertebrate community in South Africa In: Uys, M (ed) (1997), Classification of rivers and environmental health indicators. WRC Report No. TT 63/94.

[4] Hilson, G. (2000). Barriers to implementing cleaner technologies and cleaner production $(\mathrm{CP})$ practices in the mining industry: A case study of the Americas. Minerals Engineering, 13(7), 699-717.

[5] Hilson, G. 2002. Small-Scale Mining in Africa: Tackling Pressing Environmental Problems With Improved Strategy. The Journal of Environment Development 2002 11: 149-174.

[6] Hilson, G., and van der Vorst, R. 2002. Technology, Managerial, and Policy Initiatives for Improving Environmental Performance in Small-Scale Gold Mining Industry. Environmental Management Vol. 30, No. 6: 764-777

[7] Maponga, O. (1997). Small scale mining and the environment in Zimbabwe: The case of alluvial gold panning and chromite mining. In A. K. Ghose (Ed.), Small/medium scale mining (pp. 186-211). Calcutta, India: Oxford \& IBH Publishing Co. PVT Ltd.

[8] Maponga, O., and C.F., Ngorima. 2003. Overcoming environmental problems in the gold panning sector through legislation and education: the Zimbabwean experience. Journal of Cleaner Production 11: 147-157.

[9] Mondlane S., Shoko DSM., 2002 - The socio-economic and environmental impacts of artisanal and small scale mining in Mozambique. In Gavin H( ed). The socio- economic impacts of Artisanal and small Scale mining in Developing Countries. Rotterdam, The Netherland: Blackwell Publishers.

[10] Pereira, A. 2009. Environmental Impact of Artisanal Gold Mining in the Pungwe River Basin. Freiberg Online Geology. Volume 24: 45-49.

[11] Ravengai, S., Love, D., Love, I., Gratwicke, B., Mandingaisa, O. and Owen, R. 2005. Impact of Iron Duke Pyrite Mine on water chemistry and aquatic life - Mazowe valley, Zimbabwe. Water SA, 31, 219-228.

[12] Sasmaz, A., Obek, E. and Hasar, H, 2008. The accumulation of heavy metals in Typha latifolia L. grown in a stream carrying secondary effluent. Ecological Engineering 33: 278-284.

[13] Shoko, M., Maviya, J.,\& Bachs, A. (1993). Mines and environment in Zimbabwe. Gweru, Zimbabwe: Department of Natural Resources.

[14] Shoko, D.S.M., Love, D., 2005. Gold panning legislation in Zimbabwe -what potentials for sustainable management of river resources. In: Mathew, K., Nhapi, I. (Eds.), Water and Wastewater Management for Development Countries, IWAWater and Environmental Management Series. IWA Publishing, London, pp. 499-512.

[15] van Straaten, P. 2000. Mercury contamination associated with small-scale gold mining in Tanzania and Zimbabwe. The Science of the Total Environment 259: 105-113.

[16] World Bank. (1995). Staff appraisal report, republic of Ghana, mining sector development and environmental project (World Bank Report No. 13881-GH). Africa: World Bank, Industry and Energy Operations, West Central Africa Department, Africa Region.

[17] Zwane, N., Love, D., Hoko, Z., Shoko, D. 2006. Managing the impact of gold panning activities within the context of integrated water resources management planning in the Lower Manyame Sub-Catchment, Zambezi Basin, Zimbabwe. Physics and Chemistry of the Earth 31: 848-856. 